\title{
大陆深俯冲作用对邻区岩石圈地幔影响的时空范围: 以华北陆块东南部为例
}

\author{
杨德涁 ${ }^{(1 *}$, 杨进辉 ${ }^{2}$, 许文良 ${ }^{(1)}$, 裴福萍 ${ }^{(1)}$ \\ (1) 吉林大学地球科学学院, 长春 130061 ; \\ (2) 中国科学院地质与地球物理研究所, 岩石圈演化国家重点实验室, 北京 100029 \\ * 联系人, E-mail: yangdb@jlu.edu.cn
}

2013-05-16 收稿, 2013-06-21 接受, 2013-08-07 网络版发表

国家重点基础研究发展计划(2009CB825005)和国家自然科学基金(91014004, 41002018)资助

\begin{abstract}
摘要 大陆深俯冲作用对邻区岩石圈地幔影响的时空范围是大陆动力学研究的核心问题之一, 来源于大陆岩石圈地幔的火成岩为探索这一科学问题提供了重要资料. 我们对华北陆块东南部 朝鲜-辽东半岛以及辽南-吉南地区晚三叠世花岗质-镁铁质火成岩进行了详细的岩石学、同位素 年代学和地球化学研究, 结果表明它们是由华南与华北陆块俯冲碰撞后伸展过程中多元岩浆混 合形成; 相对亏损和富集地幔组分的识别标志着晚三叠世期间华北陆块东南部表现为亏损与富 集岩石圈地幔共存的属性. 鲁西-辽南-吉南地区早白严世镁铁质火成岩 $\mathrm{Sr}-\mathrm{Nd}-\mathrm{Pb}-\mathrm{Hf}$ 同位素组成 表现出与郯庐断裂距离有关的空间变化, 结合吉南地区三叠纪变质锆石和新元古代岩浆锆石的 发现, 推测起源于深俯冲华南陆块部分熔融的熔体改造了靠近邩庐断裂带的鲁西一侧(如方城、 费县、上峪)和辽南地区的岩石圈地幔，而起源于华北陆块加厚地壳部分熔融的熔体则主要改造 远离郯庐断裂带的鲁西西北部(如济南、金岭)和吉南地区的岩石圈地幔. 因此, 华南大陆深俯冲 作用对邻区华北岩石圈地幔影响的时间为晚三叠世-早白严世，影响的空间范围约为 $200 \mathrm{~km}$.
\end{abstract}

\section{关键词}

大陆深俯冲 岩石圈地幔 时空范围 岩浆作用 华北陆块
大洋地壳俯冲过程中会释放大量的流体, 形成 岛弧型的玄武岩和安山岩 ${ }^{[1]}$. 相反, 由于大陆地壳俯 冲过程中相对缺乏流体, 因此在大陆俯冲带边缘和 超高压变质带内没有发现大洋弧或大陆弧以及同俯 冲的火成岩 ${ }^{[2,3]}$. 但近年来的研究发现, 在超高压岩 石中存在许多如多硅白云母、金云母等含羟基矿物, 这表明超高压变质过程中同样存在流体活动, 特别 是在大陆深俯冲地壳的折返期间, 流体活动表现得 更为活跃 ${ }^{[4 \sim 6]}$, 这些流体交代上覆岩石圈地幔发生部 分熔融可以形成大量的同折返和碰撞后火成岩 ${ }^{[7 \sim 9]}$. 因此, 研究造山带内部和相邻地区同折返和碰撞后 火成岩的形成时代、地球化学属性和源区性质及其形 成的地球动力学背景, 对于探讨大陆深俯冲作用的
深部过程以及深俯冲陆壳对相邻岩石圈地幔影响的 时空范围具有重要意义 ${ }^{[3]}$.

早中生代时期华南陆块沿大别-苏鲁造山带俯冲 碰撞进人华北陆块之下 ${ }^{[3,10 \sim 13]}$, 这为我们研究大陆深 俯冲作用对相邻岩石圈地幔的影响提供了一个天然 的实验室. 尽管对大陆碰撞造山带内部形成的碰撞后 基性和酸性火成岩进行了年代学和地球化学的系统研 究, 确定了深俯冲大陆岩石圈物质的再循环 ${ }^{[14,15]}$, 但 大陆深俯冲作用对邻区岩石圈地幔影响的时间和空 间范围仍不清楚. 本文概括了华北陆块东南部鲁西辽南-吉南地区晚三叠世花岗质-镁铁质和早白严世 镁铁质-超镁铁质火成岩的岩石学、年代学、地球化 学和同位素组成及其空间变化, 探讨了大陆深俯冲 
作用对邻区岩石圈地幔影响的时间和空间范围.

\section{1 大陆深俯冲作用对邻区岩石圈地幔影响 的时间范围}

前人详细的年代学研究表明华南与华北陆块之 间的大陆深俯冲作用发生在早中生代 ${ }^{[3,10 \sim 13]}$, 因此, 我们通过苏鲁造山带及其邻区 (华北陆块东南缘)三 叠纪-白严纪火成岩的综合研究, 探讨大陆深俯冲作 用对华北陆块东南部岩石圈地幔影响的时间范围. 三叠纪侵人岩在苏鲁造山带、朝鲜和辽东半岛地区零 星分布 ${ }^{[8,9,16]}$. 在辽东半岛-吉南地区, 尽管前人认为 该区侵人岩主要形成于三叠纪, 但近年来的研究工 作表明，该区侵人岩主体形成于晚中生代 ${ }^{[17 ~ 20] ， 三 ~}$ 叠纪岩体相对较少, 主要包括辽宁东部的赛马-柏林 川霞石正长岩、岫岩花岗岩及其镁铁质包体、双牙山 花岗岩、老尖顶子闪长岩、于家村正长岩、尹家村辉 长岩、大和尚山辉长岩和吉林南部的龙头石英闪长岩花岗闪长岩、小苇沙河二长花岗岩、岔信子花岗闪长 岩和蚂蚁河辉石闪长岩-二长花岗岩等 ${ }^{[8,16,21 ~ 23]}$. 通过 原位微区 SIMS 和 LA-ICP-MS 锆石 U-Pb 年代学研 究表明, 除赛马-柏林川岩体相对较老(224 231 Ma), 其他岩体的形成时代主要集中在 210 221 Ma 之间, 明显晚于苏鲁造山带超高压变质时代(245 225 Ma) ${ }^{[3]}$, 说明它们形成于华南与华北陆块俯冲碰撞后的伸展 环境 ${ }^{[16,21 ~ 23]}$

全岩地球化学和锆石原位微区 Hf-O 同位素研究 表明(图 1), 辽东半岛晚三叠世镁铁质火成岩分别来 源于富集岩石圈地幔和亏损岩石圈地幔，明显区别 于华北陆块古老岩石圈地幔的属性. 晚三叠世蚂蚁 河辉石闪长岩富集大离子亲石元素和轻稀土元素、亏 损高场强元素 $(\mathrm{Nb}, \mathrm{Ta}, \mathrm{Zr}, \mathrm{Hf})$, 具有低的 $\mathrm{Nb} / \mathrm{U}(0.8 \sim$ 8.4)和 $\mathrm{Ce} / \mathrm{Pb}(3.8 \sim 7.9)$ 比值与大陆地壳组成 $(\mathrm{Nb} / \mathrm{U}=6.2$, $\mathrm{Ce} / \mathrm{Pb}=3.9)$ 相类似 ${ }^{[24]}$, 而不同于洋中脊和洋岛玄武岩 $(\mathrm{Nb} / \mathrm{U}=47, \mathrm{Ce} / \mathrm{Pb}=27)^{[25]}$. 此外, 它们具有可变的铁 石 $\delta^{18} \mathrm{O}$ 值 $\left(5.0 \%\right.$ 7.4\%o) 和 $\varepsilon_{\mathrm{Hf}}(t)$ 值 $(+2.2 \sim+7.4)$ 以及全 岩初始 ${ }^{87} \mathrm{Sr} /{ }^{86} \mathrm{Sr}$ 比值 $(0.7048 \sim 0.7053), \varepsilon_{\mathrm{Nd}}(t)(-1.8 \sim$ $+3.8)$ 和 $\varepsilon_{\mathrm{Hf}}(t)$ 值 $(+2.7 \sim+6.2)^{[16,23]}$, 和典型的与俯冲有 关的岩石特征相类似, 暗示蚂蚁河辉石闪长岩起源 于受俯冲陆壳物质改造的亏损岩石圈地幔. 上述研 究表明, 在晚三叠世该区岩石圈地幔已经受到了深 俯冲陆壳的改造 ${ }^{[16,23]}$. 同时北朝鲜晚三叠世(223 Ma) 金伯利岩中尖晶石二辉橄榄岩包体的橄榄石 $F_{0}$ 值为

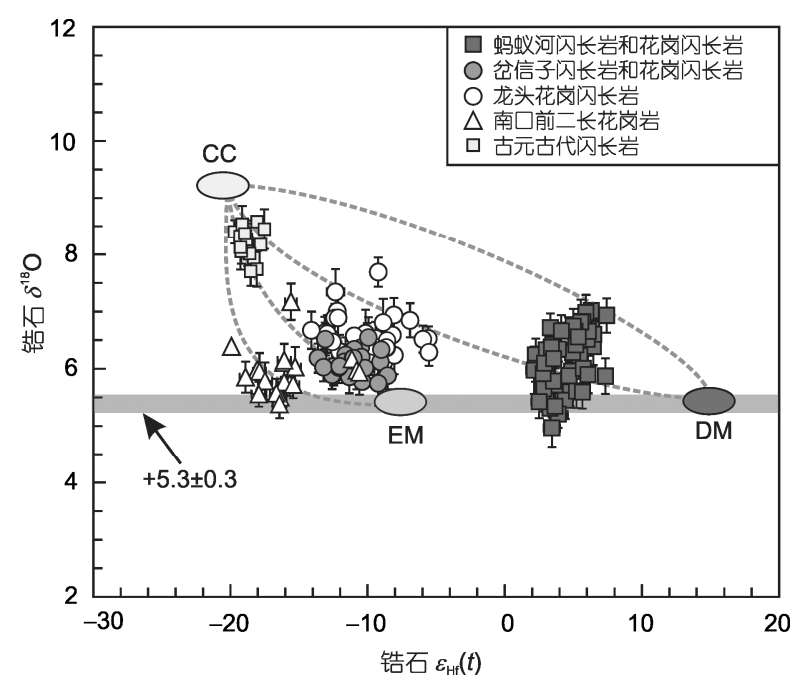

图 1 辽东半岛-吉南地区三叠纪侵入岩及镁铁质包体中锆石 Hf-O 同位素组成

据文献[16]修改

89 91、单斜辉石 $\mathrm{Na}_{2} \mathrm{O}$ 含量为 $0.46 \%$ 2.10\%、尖晶石 $\mathrm{Cr} \#$ 为 8.8 49; 全岩初始 ${ }^{187} \mathrm{Os} /{ }^{188} \mathrm{Os}$ 比值介于 $0.1245 \sim$ 0.1295 之间; 单斜辉石的初始 ${ }^{87} \mathrm{Sr} /{ }^{86} \mathrm{Sr}$ 比值介于 $0.7026 \sim$ 0.7040 之间, $\varepsilon_{\mathrm{Nd}}(t)=+6.7 \sim+13.2, \varepsilon_{\mathrm{Hf}}(t)=+15.9 \sim+24.8$. 上述特征表明, 晚三叠世北朝鲜岩石圈地幔具有新 生岩石圈地幔的属性(亏损型岩石圈地幔) ${ }^{[26]}$, 而不同 于古老的富集型岩石圈地幔. 这标志着晚三叠世华 北克拉通东延至朝鲜的大陆岩石圈地幔性质已经发 生了转变.

辽南-吉南早白严世镁铁质-超镁铁质火成岩主 要由橄榄辉石岩、辉长岩和辉长闪长岩组成, 它们的 $\mathrm{Sr}-\mathrm{Nd}-\mathrm{Pb}$ 同位素为 $\left({ }^{87} \mathrm{Sr} /{ }^{86} \mathrm{Sr}\right)_{\mathrm{i}}=0.70557 \sim 0.71119, \varepsilon_{\mathrm{Nd}}(t)=$ $-5.4 \sim-20.1,\left({ }^{206} \mathrm{~Pb} /{ }^{204} \mathrm{~Pb}\right)_{\mathrm{i}}=15.13 \sim 17.85^{[27]}$. 这些研究 结果指示, 华北陆块东南部岩石圈地幔的性质存在 明显的空间变异. 与辽南地区相比, 吉林南部镁铁质超镁铁质岩石具有高 $\mathrm{TiO}_{2}$ 和 $\mathrm{Al}_{2} \mathrm{O}_{3}$ 含量、高的 $\varepsilon_{\mathrm{Nd}}(t)$ 值、低 $(\mathrm{La} / \mathrm{Yb})_{\mathrm{N}}$ 值和低的初始 ${ }^{87} \mathrm{Sr} /{ }^{86} \mathrm{Sr}$ 比值以及低的 放射性 $\mathrm{Pb}$ 同位素组成, 指示辽南地区为富集型岩石 圈地幔, 而吉南地区为相对亏损型岩石圈地幔, 且岩 石圈地幔的厚度存在明显的差异 ${ }^{[27]}$. 此外, 辽南地 区幔源镁铁质岩石具有低的 $\varepsilon_{\mathrm{Nd}}(t)$ 值，吉南地区幔源 镁铁质岩石具有低的 $\mathrm{Pb}$ 同位素组成，这些排除了岩 浆源区被俯冲大洋板片和/或沉积物交代的可能. 结 合吉南地区镁铁质火成岩中新元古代 U-Pb 年龄岩浆 锆石和三叠纪 U-Pb 年龄变质锆石的存在 ${ }^{[27]}$, 指示该 
区受到了俯冲华南陆块地壳物质的影响. 因此, 华北 陆块东南缘晚三叠世和早白严世镁铁质火成岩与地 幔橄榄岩包体的研究表明, 深俯冲陆壳改变了华北 陆块东南缘岩石圈地幔的属性 ${ }^{[8,16,21 ~ 23]}$. 大陆深俯冲 作用对邻区岩石圈地幔影响的时间范围主要为晚三 叠世-早白严世.

\section{2 大陆深俯冲作用对邻区岩石圈地幔影响 的空间范围}

岩浆作用的空间范围和华南陆块基底物质的影 响范围可以限定华北陆块东南部岩石圈地幔受大陆 深俯冲作用改造的空间范围. 华北陆块东南部鲁西 地区早白严世幔源镁铁质火成岩具有相对低的 $\mathrm{SiO}_{2}$ 含量、 $\mathrm{Lu} / \mathrm{Hf}$ 比值和高的 $\mathrm{Mg}$ \# 和 $\mathrm{Ni} 、 \mathrm{Cr}$ 含量以及高 的 $(\mathrm{La} / \mathrm{Yb})_{\mathrm{N}}, \mathrm{Fe} / \mathrm{Mn}$ 和 $\mathrm{Th} / \mathrm{U}$ 比值, 排除了岩浆上升过 程中陆壳物质的混染. 结合它们高的初始 ${ }^{87} \mathrm{Sr} /{ }^{86} \mathrm{Sr}$ 比 值(0.7047 0.7117) 和低的 $\varepsilon_{\mathrm{Nd}}(t)$ 值(-3.92 -16.60), 可 见早白严世幔源锠铁质火成岩的岩浆源区受到了深 俯冲大陆地壳物质的改造, 而非大洋板片的改造. 此 外, 全岩 $\mathrm{Sr}-\mathrm{Nd}-\mathrm{Pb}$ 和锆石 $\mathrm{Hf}$ 同位素表现出规律的空 间变化 ${ }^{[28 ~ 30]}$, 即从东南靠近郯)庐断裂带一侧(如方城 和费县玄武岩、上峪辉长闪长岩)向北西方向(如济南 辉长岩、金岭高镁闪长岩), ${ }^{87} \mathrm{Sr} /{ }^{86} \mathrm{Sr},{ }^{207} \mathrm{~Pb} /{ }^{204} \mathrm{~Pb}$ 和 ${ }^{208} \mathrm{~Pb} /{ }^{204} \mathrm{~Pb}$ 初始比值逐渐降低, $\varepsilon_{\mathrm{Nd}}(t)$ 值和锆石 $\varepsilon_{\mathrm{Hf}}(t)$ 值 逐渐升高, 表明自南东-北西方向中生代岩石圈地幔 遭受陆壳物质的改造程度与性质是不同的 ${ }^{[28 \sim 30]}$. 结 合辽南-吉南地区早白严世镁铁质-超镁铁质火成岩 的 $\mathrm{Sr}-\mathrm{Nd}-\mathrm{Pb}$ 同位素组成以及三叠纪 U-Pb 年龄变质锆

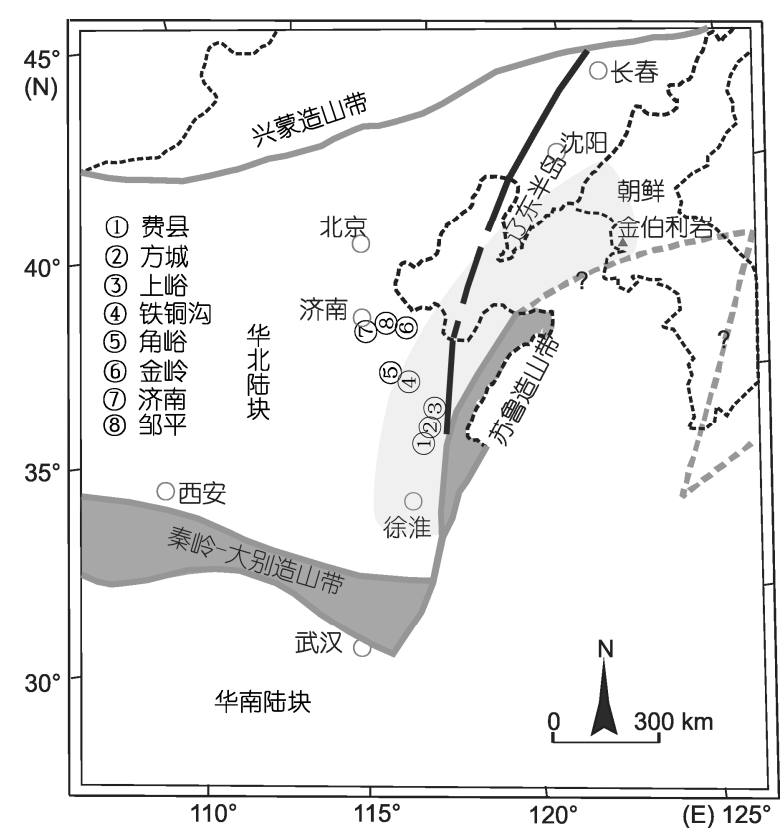

图 2 大陆深俯冲作用对华北陆块东南部岩石圈地幔影响的 空间范围

据文献[28]修改

石和新元古代 $\mathrm{U}-\mathrm{Pb}$ 年龄岩浆锆石的存在 ${ }^{[27]}$, 可以推 测 ${ }^{[27 ~ 33]}$ : (1) 起源于深俯冲华南板片部分熔融的熔体 主要改造靠近郯庐断裂带的鲁西一侧(如方城和费县 玄武岩、上峪辉长闪长岩)和辽南地区的岩石圈地幔; （2）起源于华北陆块加厚地壳部分熔融的熔体改造 的岩石圈地幔主要分布在远离郯庐断裂带的鲁西西 北部(如济南辉长岩、金岭高镁闪长岩)和吉南地区. 因此, 我们认为大陆深俯冲作用对邻区岩石圈地幔 影响的空间范围约为 $200 \mathrm{~km}$ (图 2).

\section{参考文献}

1 Lallemand S, Funiciello F. Subduction Zone Geodynamics. Heidelberg: Springer-Verlag, 2009. 1-272

2 Zheng Y F, Xia Q X, Chen R X, et al. Partial melting, fluid supercriticality and element mobility in ultrahigh-pressure metamorphic rocks during continental collision. Earth Sci Rev, 2011, 107: 342-374

3 Zheng Y F. Metamorphic chemical geodynamics in continental subduction zones. Chem Geol, 2012, 328: 5-48

4 Chen R X, Zheng Y F, Gong B, et al. Origin of retrograde fluid in ultrahigh-pressure metamorphic rocks: Constraints from mineral hydrogen isotope and water content changes in eclogite gneiss transitions in the Sulu orogen. Geochim Cosmochim Acta, 2007, 71: 2299-2325

5 Sheng Y M, Xia Q K, Yang X Z, et al. $\mathrm{H}_{2} \mathrm{O}$ contents and $D / H$ ratios of nominally anhydrous minerals from ultrahigh-pressure eclogites of the Dabie orogen, eastern China. Geochim Cosmochim Acta, 2007, 71: 2079-2103

6 Zheng Y F. Fluid regime in continental subduction zones: Petrological insights from ultrahigh-pressure metamorphic rocks. J Geol Soc London, 2009, 166: 763-782

7 Dilek Y, Altunkaynak S. Cenozoic crust evolution and mantle dynamics of post-collisional magmatism in Western Anatolia. Int Geol Rev, 2007, 49: 431-453 
8 杨进辉, 吴福元. 华北东部三叠纪岩浆作用与克拉通破坏. 中国科学 D 辑：地球科学, 2009, 39: 910-921

9 Zhao Z F, Zheng Y F, Zhang J, et al. Syn-exhumation magmatism during continental collision: Evidence from alkaline intrusives of Triassic age in the Sulu orogen. Chem Geol, 2012, 328: 70-88

10 Li S G, Jagoutz E, Lo C H, et al. $\mathrm{Sm} / \mathrm{Nd}, \mathrm{Rb} / \mathrm{Sr}$, and ${ }^{40} \mathrm{Ar} /{ }^{39} \mathrm{Ar}$ isotopic systematics of the ultrahigh-pressure metamorphic rocks in the Dabie-Sulu belt, Central China: A retrospective view. Int Geol Rev, 1999, 41: 1114-1124

11 Zheng Y F, Wang Z R, Li S G, et al. Oxygen isotope equilibrium between eclogite minerals and its constraint on mineral Sm-Nd chronometer. Geochim Cosmochim Acta, 2002, 66: 625-634

12 Liu D Y, Jian P, Kröner A, et al. Dating of prograde metamorphic events deciphered from episodic zircon growth in rocks of the Dabie-Sulu UHP complex, China. Earth Planet Sci Lett, 2006, 250: 650-666

13 Hacker B R, Wallis S R, Ratschbacher L, et al. High-temperature geochronology constraints on the tectonic history and architecture of the ultrahigh-pressure Dabie-Sulu orogen. Tectonics, 2006, 25: TC5006

14 Dai L Q, Zhao Z F, Zheng Y F, et al. Zircon Hf-O isotope evidence for crust-mantle interaction during continental deep subduction. Earth Planet Sci Lett, 2011, 308: 224-244

15 Zhang J, Zhao Z F, Zheng Y F, et al. Zircon Hf-O isotope and whole-rock geochemical constraints on origin of postcollisional mafic to felsic dykes in the Sulu orogen. Lithos, 2012, 136-139: 225-245

16 Yang J H, Sun J F, Zhang J H, et al. Petrogenesis of Late Triassic intrusive rocks in the northern Liaodong Peninsula related to decratonization of the North China Craton: Zircon U-Pb age and Hf-O isotope evidence. Lithos, 2012, 153: 108-128

17 Wu F Y, Lin J Q, Wilde S A, et al. Early Cretaceous giant igneous event in eastern China: Evidence from Liaodong Peninsula in NE China. Earth Planet Sci Lett, 2005, 233: 103-119

18 Wu F Y, Yang J H, Wilde S A, et al. Geochronology, petrogenesis and tectonic implications of the Jurassic granites in the Liaodong Peninsula, NE China. Chem Geol, 2005, 221: 127-156

19 Yang J H, Wu F Y, Wilde S A, et al. Mesozoic decratonization of the North China Block. Geology, 2008, 36: 467-470

20 Pei F P, Xu W L, Yang D B, et al. Petrogenesis of late Mesozoic granitoids in southern Jilin Province, northeastern China: Geochronological, geochemical, and Sr-Nd-Pb isotopic evidence. Lithos, 2011, 125: 27-39

21 Yang J H, Wu F Y, Wilde S A, et al. Petrogenesis of Late Triassic granitoids and their enclaves with implications for post-collisional lithospheric thinning of the Liaodong Peninsula, North China Craton. Chem Geol, 2007, 242: 155-175

22 Yang J H, Sun J F, Chen F K, et al. Sources and petrogenesis of Late Triassic dolerite dikes in the Liaodong Peninsula: Implications for postcollisional lithosphere thinning of Eastern North China Craton. J Petrol, 2007, 48: 1973-1997

23 裴福萍, 许文良, 于洋, 等. 吉林南部晚三叠世蚂蚁河岩体的成因: 锆石 U-Pb 年代学和地球化学证据. 吉林大学学报(地球科学版), 2008, 38: 351-362

24 Rudnick R L, Gao S. The composition of the continental crust. In: Rudnick R L, ed. The Crust. Oxford: Elsevier-Pergamon, 2003. 1-64

25 Hofmann A, Jochum K, Seufert M, et al. $\mathrm{Nb}$ and $\mathrm{Pb}$ in oceanic basalts: New constraints on mantle evolution. Earth Planet Sci Lett, 1986, 33: $33-45$

26 Yang J H, O'Reilly S, Walker R J, et al. Diachronous decratonization of the Sino-Korean craton: Geochemistry of mantle xenoliths from North Korea. Geology, 2010, 38: 799-802

27 Pei F P, Xu W L, Yang D B, et al. Geochronology and geochemistry of Mesozoic mafic-ultramafic complexes in the southern Liaoning and southern Jilin provinces, NE China: Constraints on the spatial extent of destruction of the North China Craton. J Asian Earth Sci, 2011, 40: 636-650

28 Yang D B, Xu W L, Pei F P, et al. Spatial extent of the influence of the deeply subducted Yangtze slab on the eastern North China Craton lithosphere: Constraints from Sr-Nd-Pb isotopic compositions of Mesozoic mafic igneous rocks in western Shandong, China. Lithos, 2012, 136-139: 246-260

29 Yang Q L, Zhao Z F, Zheng Y F. Modification of subcontinental lithospheric mantle above continental subduction zone: Constraints from geochemistry of Mesozoic gabbroic rocks in southeastern North China. Lithos, 2012, 146-147: 164-182

30 Yang Q L, Zhao Z F, Zheng Y F. Slab-mantle interaction in continental subduction channel: Geochemical evidence from Mesozoic gabbroic intrusives in southeastern North China. Lithos, 2012, 155: 442-460

31 Xu Y G., Huang X L, Ma J L, et al. Crustal-mantle interaction during the thermo-tectonic reactivation of the North China Craton: SHRIMP zircon U-Pb age, petrology and geochemistry of Mesozoic plutons in western Shandong. Contrib Mineral Petrol, 2004, 147: 750-767

32 Zhai M G, Fan Q C, Zhan H F, et al. Lower crustal processes leading to Mesozoic lithsopheric thinning beneath eastern North China: Underplating, replacement and delamination. Lithos, 2007, 96: 36-54

33 Huang X L, Zhong J W, Xu Y G. Two tales of the continental lithospheric mantle prior to the destruction of the North China Craton: Insights from Early Cretaceous mafic intrusions in western Shandong, East China. Geochim Cosmochim Acta, 2012, 96: 193-214 